\title{
KAJIAN PENYUSUNAN DATA BASE PENATAAN KECAMATAN DI KABUPATEN BANDUNG
}

\author{
Agustinus Widanarto \\ Program Studi Ilmu Pemerintahan \\ Fakultas Ilmu Sosial dan Ilmu Politik Universitas Padjadjaran Bandung \\ email: a_widanarto@yahoo.com
}

\begin{abstract}
ABSTRAK
Penelitian ini berjudul Kajian Penyusunan Data Base Penataan Kecamatan di Kabupaten Bandung, dilatarbelakangi oleh pengkajian potensi daerah dalam rangka mengukur dan mengevaluasi variabel atau kriteria potensi daerah yang dipersyaratkan untuk mengetahui kemungkinan penataan wilayah kecamatan di Kabupaten Bandung. Hasil penelitian ini diharapkan dapat dimanfaatkan sebagai bahan untuk menentukan pilihan terbaik bagi Pengembangan dan Penataan Kewilayahan di Kabupaten Bandung. Adapun tujuan penelitian ini adalah untuk mengetahui gambaran tingkat kemampuan daerah dalam mengimplementasikan otonomi daerah, dan untuk mengetahui kemungkinan pengembangan dan penataan seluruh wilayah di Kabupaten Bandung untuk dilakukan pengembangan dan penataan di tingkat kecamatan. Penelitian ini merupakan aplikasi model pengukuran dan evaluasi terhadap kemampuan potensi yang akan mendiskripsikan dan mengeksplanasikan tingkat kekuatan atau pengaruh variabel yang diamati terhadap keberhasilan penyelenggaraan pemerintahan, untuk meningkatkan penyelenggaraan pelayanan umum, pembangunan dan demokratisasi. Melalui pendekatan ini dapat diketahui secara obyektif dan mendalam tingkat kemampuan potensi yang dimiliki kecamatan dalam penyelanggaraan pemerintahan melalui pengukuran terhadap indikator dan sub indikator dari berbagai variabel yaitu: demografi, orbitasi, pendidikan kesehatan, prasarana ibadah, sarana olah raga, transportasi, komunikasi, penerangan umum, kesadaran politik, keamanan dan ketertiban masyarakat, pertanian, perikanan, peternakan, ketenagakerjaan, sosial budaya, ekonomi masyarakat, sosial masyarakat, dan aspek pemerintahan. Data primer dan sekunder diambil dari 31 (tigapuluh satu) kecamatan di Kabupaten Bandung, berupa data kualitatif dan data kuantitatif. Suatu kecamatan dapat dimekarkan jika kecamatan memiliki potensi dalam interval tinggi $(1.008 \leq \mathrm{TS}<1.680)$. Dapat dimekarkan dengan syarat jika potensinya dalam interval $(644 \leq \mathrm{TS}<1.008)$, dan dinyatakan tidak lulus atau ditolak untuk dimekarkan jika masing-masing kecamatan hanya mencapai total skor kurang dari 644. Hasil penilaian dan pengukuran terhadap potensi kecamatan di Kabupaten Bandung dapat dijelaskan sebagai berikut : Skoring data sekunder monografi desa terhadap 31 kecamatan yang akan dimekarkan diperoleh hasil bahwa terdapat 14 (empat belas) kecamatan dalam kategori layak dimekarkan yaitu, kecamatan: Rancabali, Pangalengan, Pacet, Cicalengka, Nagreg, Rancaekek, Majalaya, Ciparay, Baleendah, Margaasih, Margahayu, Dayeuhkolot, Bojongsoang, dan Cileunyi.
\end{abstract}

Kata Kunci: Kajian Penataan; Penataan Kecamatan; Pengembangan Kabupaten Bandung

\section{ABSTRACT}

The title of this research was A Study of the Creation of a Database for an Arrangement of Localities in Bandung District. Its background was a study of local potentials in attempt to measure and evaluate the variables or criteria of the local potentials required to know a possible arrangement of localities in Bandung District. The research results 
were expectedly useful as a material in determining the best choice for the Regional Development and Arrangement in Bandung District. The objective of the research was to obtain a description on the capacity of localities in implementing regional autonomy, and to know the possibility of development and arranging the whole localities in Bandung District to perform development and arrangement in kecamatan (sub district) level. The research was an application of measurement and evaluation models to the capacity of the potentials that describe and explain the strength level or effect of the observed variables on the success of governmental implementation, in order to enhance the implementation of public services, development, and democratization. By the approach, it could be found out objectively and deeply the capacity of the potensials that the sub-distric possess in implementing governance by measuring the indicators and sub-indicators of some variables, namely: demography,orbitation, health education, religious facility, sport facility, transportation, communication, public lighting, political awareness, security and social order, agriculture, fishoing, husbandry, labor, social-cultural, community economy, social community, and administrative aspects. Both primary and secondary data were obtained from 31 (thirty one) sub- districs in Bandung District, in form of qualitative and quantitative data. A sub- district might be split if it owns potentials at a high interval $(1.008 \leq T S<1.680)$. It might be split on condition that its potentials were at an interval of (644 $\leq T S<1.008)$, and decided as fail or rejected to be split if a subdistrict achieved a total score of less than 644. The evaluation and measurement results of the potentials of sub-district in Bandung District could be explained as follows: The scoring of village monographic secondary data on the 31 sub-districs to be split produced a result that there were 14 (fourteen) sub-districts falling into a category of being feasible to split, namely: Rancabali, Pangalengan, Pacet, Cicalengka, Nagreg, Rancaekek, Majalaya, Ciparay, Baleendah, Margaasih, Margahayu, Dayeuhkolot, Bojongsoang, and Cilaunyi.

Keywords: arragement study; arragement of sub-district; development in district of Bandung

\section{PENDAHULUAN}

Masyarakat memerlukan pemerintah karena banyak bagian penting dari kebutuhannya yang tidak dapat dipenuhi oleh organisasi lain seperti organisasi swasta profit maupun organisasi non profit. Organisasi swasta profit akan gagal memenuhi kebutuhan masyarakat menyangkut eksternalitas dan barang publik. Begitu pula halnya dengan organisasi swasta non profit hanya mampu memberikan pelayanan dalam skala kecil dan sederhana, serta terbatas pada lapisan masyarakat tertentu.
Organisasi pemerintah selain memiliki misi menyelenggarakan pelayanan publik, juga memiliki misi lainnya, seperti fungsi pengaturan kehidupan masyarakat, baik menyangkut pengaturan persaingan maupun pengaturan terhadap perlindungan masyarakat. Hal ini sejalan dengan pendapat Rasyid (dalam Widodo, 2001:269) yang menyatakan bahwa:

Pemerintah tidaklah diadakan untuk melayani dirinya sendiri, tetapi untuk melayani masyarakat serta menciptakan kondisi yang memungkinkan setiap anggota 
masyarakat mengembangkan kemampuan dan kreatifitasnya demi mencapai tujuan bersama. Karenanya birokrasi publik berkewajiban dan bertanggung jawab untuk memberikan layanan publik yang baik dan profesional. Pandangan umum mengakui bahwa pemerintahan yang sentralistik semakin kurang populer, karena ketidakmampuannya untuk memahami secara tepat nilai-nilai daerah atau sentimen aspirasi lokal. Alasannya, warga masyarakat akan lebih aman dan tentram dengan pemerintah daerah yang lebih dekat dengan rakyat, baik secara fisik maupun psikologis. Dewasa ini dampak dari globalisasi telah merubah lingkungan kehidupan manusia dari berbagai aspek, masyarakat semakin cerdas dan kritis terhadap segala perubahan yang terjadi. Kondisi ini pada gilirannya menuntut pemerintah dapat menjalankan fungsinya sebagai pelayan masyarakat (Public Service) dapat dilaksanakan secara responsif dan aspiratif.

Pemerintah dimaksud adalah pemerintah daerah (local government) yang menurut Undangundang Nomor 32 Tahun 2004 menyatakan bahwa "Pemerintah daerah adalah kepala daerah beserta perangkat daerah otonom yang lain sebagai badan eksekutif daerah". Pemerintah daerah inilah yang diberi kewenangan untuk melaksanakan otonomi daerah. Hal ini sejalan dengan pendapat Common, Flynn and Melon (1992:139) yang menyatakan Bahwa “...... one of It's main recommendations was to give much greater autonomy to managers at the local level". Namun kedekatan posisi saja belumlah menjamin terpenuhinya kebutuhan masyarakat, karena yang lebih penting adanya hal dan kewenangan yang dimiliki oleh pemerintah daerah untuk mengatur dan mengurus kebutuhan masyarakatnya.

Menurut Rasyid (1997), salah satu cara untuk mendekatkan pemerintah kepada masyarakat adalah dengan menerapkan kebijakan desentralisasi, sedangkan Riwu Kaho (1988) menyatakan bahwa "sebagai akibat dari pelaksanaan desentralisasi timbullah daerah otonom"

Menurut Undang-Undang Nomor 32 Tahun 2004, bahwa daerah otonom adalah "kesatuan masyarakat hukum yang mempunyai batas daerah tertentu, yang berwenang mengatur dan mengurus kepentingan masyarakat setempat menurut prakarsa dalam ikatan Negara Kesatuan Republik Indonesia.

Ndraha (2001) menyebutkan bahwa ada lima posisi daerah yaitu : (1) sebagai masyarakat hukum, (2) sebagai unit usaha ekonomi, (3) sebagai suatu lingkungan budaya, (4) sebagai satuan lingkungan, dan (5) sebagai subsistem politik.

Dengan demikian akan semakin tepat bila desentralisasi tersebut diselenggarakan oleh daerah sehingga masyarakat akan lebih 
dekat dengan pemerintah yang akan sering terjadi kontak baik secara fisik maupun psikologis. Daerah yang wilayahnya terlalu luas akan menyulitkan jangkauan pemerintah untuk melayani masyarakatnya, daerah yang demikianlah yang perlu ditata (pemekaran) menjadi beberapa daerah sehingga rentang kendali menjadi semakin dekat dan pelayanan kepada masyarakat menjadi terjangkau, karena rentang kendali dan proporsi perlakuan dan tindakan pelayanan yang tidak seimbang adalah embrio awal untuk pembentukan suatu daerah otonom baru bukanlah karena nuansa politis.

Konsekuensi dari penataan (pemekaran) daerah secara praktis akan terjadi perubahan struktur organisasi pemerintahan, perubahan luas wilayah yang diikuti dengan perubahan batas-batas wilayah dan perubahan jumlah penduduk. Perubahan ini akan berimplikasi terhadap perubahan-perubahan lain yang lebih esensial, khususnya dalam upaya pemberian pelayanan kepada masyarakat.

Penataan (Pemekaran dan Penggabungan) daerah dalam hal ini dapat dipandang sebagai upaya pengembangan organisasi untuk menghadapi berbagai tantangan perkembangan jaman dan tuntutan pelayanan dari masyarakat minimal optimal terhadap pelayanan kebutuhan dasar manusia (basic Need) seperti pendidikan dan kesehatan. Organisasinya diharapkan dapat menyesuaikan diri dengan melakukan perubahan-perubahan berencana yang selanjutnya dapat menjamin optimalisasi dan efektifitas pelaksanaan fungsi pemerintahan. Sebagaimana dijelaskan oleh Sadu Wasistiono (2001) bahwa tujuan organisasi pemerintahan daerah dibentuk adalah (1) untuk melayani kepentingan masyarakat sebagai warga yang berposisi sebagai konsumen (Customer) dan pemegang saham (stakeholders) dan (2) adanya misi tertentu yang harus dijalankan dalam rangka pencapaian tujuan, bukan hanya sekedar menjalankan perundang-undangan.

Perubahan struktur organisasi dan rentang wilayah provinsi yang diikuti dengan pengurangan jumlah kabupaten/kota, kecamatan, dan kelurahan akan berimplikasi terhadap perubahan rentang kendali pimpinan organisasi. Rentang pengawasan yang dilaksanakan aparat akan lebih sempit dibanding sebelum penataan (pemekaran), sehingga aparat mempunyai kesempatan yang lebih banyak untuk memberikan perhatian dan pengendalian terhadap sumber daya manusia dan sumber daya alam diwilayahnya. Pada hakekatnya pelayanan kepada masyarakat tidaklah semata-mata aktivitas pemerintah. Keberhasilan jalannya pemerintahan dan pembangunan justru memerlukan keterlibatan masyarakat. Begitu pula keberhasilan penataan (pemekaran) daerah juga perlu didukung oleh masyarakat termasuk pengawasan yang dijalankan masyarakat yang disebut 
pengawasan sosial. Ramses (2003) mengatakan bahwa "pemekaran wilayah atau tepatnya membagi suatu daerah otonom menjadi beberapa daerah, bertujuan untuk mendekatkan dan mengoptimalkan pelayanan pemerintah kepada masyarakat, mempercepat pertumbuhan pembangunan guna meningkatkan kesejahteraan masyarakat di daerah tersebut. Partisipasi masyarakat akan meningkat karena akses yang lebih terbuka serta pengawasan yang lebih efektif karena wilayah pengawasan relatif lebih sempit".

Perubahan luas wilayah atau batas-batas daerah membawa konsekuensi terhadap jangkauan komunikasi antara pemerintah dengan masyarakat karena peluang terjadinya gangguan pada saluran komunikasi dapat diperkecil. Dengan semakin dekatnya jarak antara wilayah provinsi dengan kabupaten maupun provinsi dengan kecamatan dan provinsi dengan kelurahan maka informasi dari provinsi akan cepat sampai kepada masyarakat baik di kabupaten, kecamatan maupun desa/kelurahan.

Struktur dan luas wilayah yang lebih sempit berimplikasi juga pada aktifitas koordinasi struktur dengan unit organisasi yang ramping sesuai dengan prinsip "ramping struktur kaya fungsi" dengan demikian koordinasi yang dilakukan akan lebih mudah. Menurut Kristiadi (dalam Lotulung, 1994) bahwa keuntungan organisasi ramping antara lain : (1) pelayanan kepada masyarakat akan menjadi lebih baik karena prosedur lebih pendek dan pengambilan keputusan lebih cepat, (2) komunikasi antar tingkatan manajemen menjadi lebih lancar, dan (3) koordinasi akan menjadi lebih lancar.

Berdasarkan pendapat tersebut di atas, maka dimensi utama yang menjelaskan efektif tidaknya penataan (pemekaran) daerah adalah pengawasan, komunikasi, dan koordinasi yang kesemuanya turut menentukan terhadap tingkat pelayanan masyarakat. Semakin jauh penduduk dari pusat pemerintahan, semakin kecil memperoleh sentuhan pelayanan. Permintaan terhadap pelayanan semakin meningkat menuntut pusat-pusat pemerintahan memperluas daerah layanannya. Akan tetapi pusat-pusat pelayanan memiliki keterbatasan (radius) jangkauan, sehingga diperlukan pusat-pusat pelayanan lain yang dapat memenuhi kebutuhan pelayanan masyarakat. Dengan demikian dengan adanya penataan (pemekaran) daerah berarti menambah pusat-pusat pemerintahan sehingga pelayanan dapat menjangkau wilayah-wilayah pemukiman yang sebelumnya terpencil dan pelayanan pemerintah dapat tersentuh secara merata ke seluruh masyarakat yang pada akhirnya akan meningkatkan kesejahteraan masyarakat.

Pemerintah telah menetapkan kebijakan otonomi daerah yang luas, 
nyata dan bertanggung jawab. Menurut Undang-undang Nomor 32 Tahun 2004 tentang Pemerintahan Daerah pada Bab I Pasal 1 huruf 5 dikemukakan bahwa "Otonomi Daerah adalah hak, wewenang, dan kewajiban daerah otonom untuk mengatur dan mengurus sendiri urusan pemerintahan dan kepentingan masyarakat setempat sesuai dengan peraturan perundangundangan".

Implementasi kebijakan

desentralisasi berdasarkan Undangundang Nomor 22 Tahun 1999 telah berlangsung sejak Januari 2001, hingga saat ini hampir 6 (enam) tahun (setelah dikeluarkannya Undang-undang nomor 32 Tahun 2004), telah banyak ditetapkan berbagai undang-undang tentang penataan daerah (baik pemekaran/pembentukan provinsi, kabupaten dan kota).

Dalam perjalanan implementasi kebijakan otonomi daerah sejak dikelurakannya Undang-undang Nomor 22 Tahun 1999 hingga digantinya Undangundang Nomor 22 tahun 1999, telah banyak dilakukan pembentukan daerah otonom baru. Hal ini dapat dimaklumi karena pemekaran/pembentukan daerah dimaksudkan untuk mendekatkan pelayanan organisasi pemerintah kepada masyarakat. Melalui pemekaran/pembentukan daerah diharapkan tujuan kebijakan otonomi daerah seperti peningkatan pelayanan, demokratisasi dan pemberdayaan masyarakat dapat terwujud.

Adanya aspirasi yang berkembang yang menghendaki dilakukannya pengembangan dan penataan daerah di Kabupaten Bandung perlu mendapat respon dari berbagai pihak terutama dari jajaran DPRD Kabupaten sebagai wakil rakyat dan pemerintah daerah. Hal ini seiring dengan penjelasan Undang-Undang Nomor 32 Tahun 2004 bahwa penyelenggaraan otonomi daerah harus selalu berorientasi pada peningkatan kesejahteraan masyarakat dengan selalu memperhatikan kepentingan dan aspirasi yang tumbuh dalam masyarakat khususnya membuka isolasi wilayah adminsitrasi Kabupaten Bandung sebagai satu kesatuan masyarakat hukum, unit usaha ekonomi, lingkungan budaya, satuan lingkungan, dan sebagai subsistem politik dari Provinsi Jawa Barat.

Persoalannya apakah aspirasi yang muncul ini dapat menjamin peningkatan pelayanan umum dan kesejahteraan bagi seluruh masyarakat di Kabupaten Bandung dan sekitarnya. Untuk kepentingan tersebut perlu terlebih dahulu dilakukan pengkajian terhadap potensi dan masalah yang ada di Provinsi Jawa Barat Khususnya di Kabupaten Bandung, sekaligus menggali aspirasi masyarakat.

Pengkajian kemungkinan
pengembangan dan penataan
kewilayahan (Daerah otonom) di


Provinsi Jawa Barat khususnya pengembangan dan penataan kewilayahan Kabupaten Bandung sejalan dengan Undang-undang Nomor 32 Tahun 2004 Pasal 4 ayat (3) yang menyebutkan bahwa "pembentukan daerah dapat berupa penggabungan beberapa daerah atau bagian daerah yang bersandingan atau pemekaran dari satu daerah menjadi dua daerah atau lebih". Salah satu prosedur pembentukan/pemekaran daerah menurut Peraturan Pemerintah Nomor 129 Tahun 2000 jo. PP Nomor 78 Tahun 2007 bahwa ada kemauan politik dari pemerintahan daerah dan masyarakat yang bersangkutan.

Di samping itu pengkajian ini juga dimaksudkan untuk memenuhi syarat lainnya, seperti tersebut dalam Peraturan Pemerintah Nomor 129 Tahun 2000 jo PP Nomor 78 Tahun 2007 bahwa pemekaran daerah dapat dilakukan berdasarkan kriteria kemampuan ekonomi, potensi daerah, sosial budaya, sosial politik, jumlah penduduk, luas daerah, dan pertimbangan lain yang memungkinkan terselenggaranya Otonomi Daerah. Dalam penjelasan peraturan pemerintah dimaksud disebutkan pula bahwa pembentukan, pemekaran, penghapusan dan penggabungan daerah otonom memerlukan penilaian dengan menggunakan indikator yang tersedia.

Sehubungan dengan hal di atas, diperlukan pengkajian potensi daerah dalam rangka mengukur dan mengevaluasi variabel atau kriteria potensi daerah yang dipersyaratkan untuk mengetahui kemungkinan penataan wilayah di Provinsi Jawa Barat khususnya Kabupaten Bandung melalui penelitian mendalam terhadap "Kajian Penyusunan Data Base Penataan Kecamatan di Kabupaten Bandung" Hasil penelitian ini diharapkan dapat dimanfaatkan sebagai bahan acuan bagi DPRD dan Pemerintah Daerah Kabupaten Bandung untuk menentukan pilihan terbaik bagi Pengembangan dan Penataan Kewilayahan di Kabupaten Bandung. Tujuan penelitian ini adalah :

1) Untuk Mengetahui gambaran tingkat kemampuan daerah Khususnya Kabupaten Bandung dalam mengimplementasikan otonomi daerah;

2) Untuk Mengetahui kemungkinan pengembangan dan penataan seluruh wilayah di Kabupaten Bandung untuk dilakukan pengembangan dan penataan di tingkat Kecamatan (pemekaran Kecamatan);

\section{TINJAUAN PUSTAKA}

Penataan/Pembentukan suatu daerah otonom setidaknya harus memenuhi syarat administrasi, teknis dan fisik kewilayahan. Syarat administrasi untuk provinsi meliputi adanya persetujuan DPRD kabupaten/kota dan bupati/walikota 
yang akan menjadi cakupan wilayah provinsi, persetujuan DPRD provinsi induk dan Gubernur, serta rekomendasi Menteri Dalam Negeri. Sedangkan syarat administrasi untuk kabupaten/kota meliputi adanya persetujuan DPRD kabupaten/ kota dan bupati/walikota yang bersangkutan, persetujuan DPRD provinsi dan Gubernur serta rekomendasi Menteri Dalam Negeri.

Selain itu, dalam penjelasan Pasal 4 ayat (4) Undang-undang Nomor 32 Tahun 2004 disebutkan bahwa pemekaran suatu daerah menjadi 2 (dua) daerah atau lebih setelah mencapai batas minimal usia penyelenggaraan pemerintahan, untuk provinsi adalah 10 tahun, kabupaten/kota 7 tahun sedang kecamatan 5 tahun.

Dalam konteks upaya pengembangan dan penataan wilayah di Provinsi Jawa Barat khususnya Kabupaten Bandung, permasalahan yang dapat dirumuskan adalah sebagai berikut:

1) Bagaimanakah potensi wilayah kecamatan di Kabupaten Bandung dalam mengimplementasikan otonomi daerah?

2) Bagaimana pemetaan kecamatan di Kabupaten Bandung, sebagai peluang untuk pemekaran kecamatan? Masalah penelitian dibatasi dengan fokus Peraturan Pemerintah Nomor 129 Tahun 2000 jo PP Nomor 78 Tahun 2007 berupa pengukuran dan penilaian terhadap variabel yang merupakan persyaratan pembentukan dan kriteria pemekaran daerah, meliputi kemampuan ekonomi, potensi daerah, sosial budaya, sosial politik, jumlah penduduk/kependudukan, luas wilayah dan pertimbangan lain yang memungkinkan terselenggaranya otonomi daerah seperti faktor keamanan, ketersediaan sarana pemerintahan, dan rentang kendali.

\section{METODE PENELITIAN}

Penelitian ini merupakan aplikasi model pengukuran dan evaluasi terhadap kemampuan potensi yang akan mendeskripsikan dan mengeksplanasikan tingkat kekuatan atau pengaruh variabel yang diamati terhadap keberhasilan penyelenggaraan pemerintahan di unit terkecil dan terdepan untuk meningkatkan penyelenggaraan pelayanan umum, pembangunan dan demokratisasi.

Melalui pendekatan ini dapat diketahui secara obyektif dan mendalam tingkat kemampuan potensi yang dimiliki kecamatan dalam penyelenggaraan pemerintahan melalui pengukuran terhadap indikator dan sub indikator dari berbagai variabel yaitu : demografi, orbitasi, pendidikan, kesehatan, prasarana ibadah, sarana olah raga, transportasi, komunikasi, penerangan umum, kesadaran politik, keamanan dan ketertiban masyarakat, pertanian, perikanan, peternakan, ketenagakerjaan, sosial 
budaya, ekonomi masyarakat, sosial masyarakat, dan aspek pemerintahan.

Berdasarkan identifikasi terhadap tingkat kemampuan potensi tersebut, dapat disusun berbagai alternatif desain pemekaran kecamatan, dan dapat ditentukan pilihan prioritas tindakan guna peningkatan potensi kecamatan.

Unit analisis dalam penelitian ini adalah 31 (tiga puluh satu) kecamatan di Kabupaten Bandung Provinsi Jawa Barat. Satuan sampel yang menjadi obyek penelitian ini adalah Camat. Penarikan sampel sebagai obyek penelitian dalam ukuran dan jumlah yang representatif, dengan menggunakan teknik penarikan total sampling atau sampel jenuh, dimana setiap kecamatan diambil seluruhnya. Data yang diperlukan dalam penelitian ini adalah data kuantitatif dan kualitatif dengan sumber data terdiri atas:

1) Data Primer, diperoleh dengan penelitian lapangan, dilakukan dengan jalan meminta data kepada pihak kecamatan, dengan mengisi kuesioner penelitian yang telah disediakan.

2) Data Sekunder, dikumpulkan untuk melengkapi data primer, baik yang tersedia di BPS setempat, Sekretariat Daerah, Bappeda, Dinasdinas Daerah, badan/kantor, kecamatan, dan instansi lain yang relevan dengan topik penelitian ini. Data sekunder diperoleh melalui penelitian terhadap dokumen, laporan dan bahan kepustakaan lainnya.

Teknik pengumpulan data yang dipilih dalam penelitian lapangan adalah:

1) Kuesioner, penyebaran angket atau daftar pertanyaan yang telah tersedia yang relevan dengan masalah yang diteliti. Kuesioner ini dimaksudkan untk memperoleh data yang merupakan salah satu pengumpulan data yang diketahui dan dipahami oleh responden sehingga hasilnya obyektif;

2) Studi Literatur, mengumpulkan data dengan mempelajari, menelaah dan menganalisis literatur, dokumen, peraturan serta referensi lainnya yang erat kaitannya dengan masalah yang diteliti

Data kualitatif dianalisis melalui pendekatan isi dan kedalaman menterjemahkan suatu fenomena terhadap 19 variabel penelitian. Cara mengakomodasi analisis kulitatif adalah dengan menstimulasi berbagai kecenderungan jawaban kualitatif dari responden terhadap fenomena tersebut.

Dalam konteks ini sebagian dari data kualitatif direnovasi menjadi data kuantitatif melalui non- 
parametric process. Sedangkan data kuantatif dikategorikan, diklasifikasi dan diolah sebagai dasar pengukuran dan analisis untuk memberikan penjelasan dan penilaian terhadap kekuatan dan kelemahan variabel penelitian.

Kategori penilaian beradasarkan skala tertentu dan ditetapkan menurut klasifikasi layak, cukup layak dan tidak layak berdasarkan jumlah skor tertentu yang representatif. Setiap kategori menjadi penilaian menjadi dasar pilihan tindakan untuk pemekaran kecamatan dan pendayagunaan potensi.

Metode penilaian ditetapkan melalui metode distribusi yaitu metode rata-rata yang mempertimbangkan distribusi data. Perhitungan skor dengan metode ini disesuaikan dengan kemencengan dan keruncingan kurva sebaran data. Setiap sub indikator mempunyai skor 1 untuk nilai terkecil dan skor 6 untuk nilai terbesar. Skoring dilakukan dengan cara sebagai berikut:

a. Menghitung rata-rata, standar deviasi, dan koefisiens kurtosis/skewness.

b. Menghitung batas 2 (nilai $2 \mathrm{X}$ kurtosis/Skewness $\mathrm{X}$ standar deviasi), dan batas 1 (nilai $1 \mathrm{X}$ kurtosis X standar deviasi) dan;

c. Menentukan kelas indeks untuk penentuan skor:

(i) Jika nilai indikator > ratarata + batas 2 , mendapat skor 6; (ii) Jika rata-rata + batas $2 \leq$ nilai indikator < ratarata+batas 1 , mendapat skor 5 ;

(iii) Jika rata-rata + batas $1 \leq$ nilai indikator < rata-rata, mendapat skor 4;

(iv) Jika rata-rata $\leq$ nilai indikator < rata-rata - batas 1, mendapat skor 3;

(v) Jika rata-rata - batas $1 \leq$ nilai indikator < rata-rata batas 2, mendapat skor 2;

(vi) Jika nilai indikator $\leq$ ratarata - batas 2, mendapat skor 1 ;

Asumsi yang digunakan di dalam pembobotan adalah setiap variabel atau kriteria mempunyai bobot yang berbeda sesuai dengan perannya dalam penyelenggaraan pemerintahan, pembangunan dan kemasyarakatan. Bobot untuk pelayanan dasar seperti : bobot demografi, orbitrasi, kesadaran politik, pertanian, sosial budaya, dan aspek pemerintahan adalah 5, bobot sarana ibadah, sarana olah raga, kamtibmas, perikanan, peternakan adalah 3, sarana kesehatan dan pendidikan adalah 11 , bobot fasilitas transportasi, komunikasi dan penerangan umum adalah 7 , bobot kondisi sosial masyarakat adalah 2 . Selanjutnya, skor minimal kelulusan adalah jumlah total skor sub indikator pada setiap variabel/kelompok kriteria dikalikan dengan skor di atas rata-rata untuk setiap variabel atau kelompok 
kriteria dikali bobot untuk setiap kelompok indikator.

Perhitungan skor total maksimum dan minimum dari setiap dan seluruh variabel dapat dapat dilihat pada Tabel 3.1 berikut :

Tabel 3.1

Nilai maksimum dan minimum variabel/kriteria

\begin{tabular}{|c|c|c|c|c|c|c|c|}
\hline NO & VARIABEL & $\begin{array}{c}\text { JUMLAH } \\
\text { INDIKATOR }\end{array}$ & ВОВОТ & $\begin{array}{c}\text { NILAI } \\
\text { MIN }\end{array}$ & $\begin{array}{l}\text { NILAI } \\
\text { MAKS }\end{array}$ & $\begin{array}{c}\text { TOTAL } \\
\text { SKOR } \\
\text { MINIMAL }\end{array}$ & $\begin{array}{c}\text { TOTAL } \\
\text { SKOR } \\
\text { MAKSIMAL }\end{array}$ \\
\hline 1 & 2 & 3 & 4 & 5 & 6 & 7 & 8 \\
\hline 1 & DEMOGRAFI & 3 & 5 & 1 & 6 & 15 & 90 \\
\hline 2 & ORBITASI & 2 & 5 & 1 & 6 & 10 & 60 \\
\hline 3 & PENDIDIKAN & 4 & 11 & 1 & 6 & 44 & 264 \\
\hline 4 & KESEHATAN & 5 & 11 & 1 & 6 & 55 & 330 \\
\hline 5 & KEAGAMAAN & 1 & 3 & 1 & 6 & 3 & 18 \\
\hline 6 & OLAH RAGA & 1 & 3 & 1 & 6 & 3 & 18 \\
\hline 7 & TRANSPORTASI & 1 & 7 & 1 & 6 & 7 & 42 \\
\hline 8 & KOMUNIKASI & 1 & 7 & 1 & 6 & 7 & 42 \\
\hline 9 & PENERANGAN UMUM & 2 & 7 & 1 & 6 & 14 & 84 \\
\hline 10 & KESADARAN POLITIK & 3 & 5 & 1 & 6 & 15 & 90 \\
\hline 11 & KAMTIBMAS & 2 & 3 & 1 & 6 & 6 & 36 \\
\hline 12 & PERTANIAN & 2 & 5 & 1 & 6 & 10 & 60 \\
\hline 13 & PERIKANAN & 2 & 3 & 1 & 6 & 6 & 36 \\
\hline 14 & PETERNAKAN & 2 & 3 & 1 & 6 & 6 & 36 \\
\hline 15 & KETENAGAKERJAAN & 3 & 3 & 1 & 6 & 9 & 54 \\
\hline 16 & SOSIAL BUDAYA & 3 & 5 & 1 & 6 & 15 & 90 \\
\hline 17 & EKONOMI MASYARAKAT & 3 & 7 & 1 & 6 & 21 & 126 \\
\hline 18 & KONDISI SOSIAL MASYARAKAT & 2 & 2 & 1 & 6 & 4 & 24 \\
\hline 19 & ASPEK PEMERINTAHAN & 6 & 5 & 1 & 6 & 30 & 180 \\
\hline \multicolumn{6}{|c|}{ JUMLAH } & 280 & 1.680 \\
\hline
\end{tabular}

Skor minimal kelulusan adalah jumlah sub indikator pada setiap variabel/kelompok kriteria dikali skor di atas rata-rata untuk setiap variabel atau kelompok kriteria dikali bobot untuk setiap kelompok indikator. Asumsi yang digunakan adalah nilai di atas rata-rata untuk setiap variabel adalah di atas 3,6. Jelasnya dapat dilihat pada Tabel 3.2 di bawah ini :

Berdasarkan uraian di atas terlihat bahwa skor di atas rata-rata adalah 1.008. Ini berarti suatu 
kecamatan yang akan dilakukan

pengukuran mencapai skor sama pemekaran kecamatan dinyatakan dengan atau lebih dari 1.008. Atas lulus/memenuhi persyaratan atau mampu menyelenggarakan pemerintahannya jika hasil dasar itu, dapat ditetapkan kategori penilaian terhadap kemampuan daerah.

\begin{tabular}{|c|c|c|l|}
\hline NO & KATEGORI & $\begin{array}{c}\text { INTERVAL } \\
\text { SKOR } \\
\text { TOTAL }\end{array}$ & \multicolumn{1}{|c|}{ KESIMPULAN } \\
\hline \hline $\boldsymbol{1}$ & $\mathbf{2}$ & $\mathbf{3}$ & $\mathbf{4}$ \\
\hline 1 & Potensinya Tinggi & $1.008 \leq \mathrm{TS}<1.680$ & Layak dimekarkan \\
\hline 2 & Potensinya Cukup & $644 \leq \mathrm{TS}<1.008$ & $\begin{array}{l}\text { Cukup layak dimekarkan diikuti } \\
\text { pengembangan potensinya dalam } \\
\text { waktu tertentu }\end{array}$ \\
\hline 3 & Potensinya Rendah & $280 \leq \mathrm{TS}<644$ & $\begin{array}{l}\text { Tidak layak dimekarkan, } \\
\text { dikembangkan potensinya menuju } \\
\text { kategori Cukup Layak }\end{array}$ \\
\hline
\end{tabular}

\section{Dapat dijelaskan bahwa} seluruh perhitungan dan analisa statistik dalam tulisan ini menggunakan alat bantu komputer dengan paket program SPSS For MS Windows Release 15.0 dan Microsoft Excel. Perbandingan sebagaimana dipaparkan di atas sifatnya adalah relatif, artinya apabila terjadi perubahan data/informasi mengenai potensi masing-masing indikator/sub indikator, maka perhitungan awal akan berubah. Perubahan ini otomatis akan mempengaruhi perolehan skor total seluruh desa.

Selanjutnya membandingkan potensi kecamatan antara potensi tertinggi dengan potensi terendah, adapun rumus-rumus yang digunakan adalah:
Selisih $($ Range $)=$ Nilai Maksimal Nilai Minimal

Persentase potensi $=$ Nilai Range/Nilai Maksimal dikali 100\% Kriteria potensi kecmatan yang diasumsikan baik sehingga layak dimekarkan adalah $20-30 \%$ dari potensi kecamatan terendah.

\section{HASIL PENELITIAN DAN PEMBAHASAN}

Dari uraian di atas dapat dirangkum potensi wilayah kecamatan di Kabupaten Bandung sudah layak, cukup layak atau tidak layak untuk dimekarkan tercantum pada tabel di bawah ini. 
Tabel 4.1

Rangkuman Potensi Wilayah Kecamatan di Kabupaten Bandung

\begin{tabular}{|c|c|c|c|c|c|}
\hline NO & KABUPATEN & KECAMATAN & $\begin{array}{l}\text { TOTAL } \\
\text { SKOR }\end{array}$ & INTERVAL SKOR & KATEGORI \\
\hline 1 & \multirow{31}{*}{ BANDUNG } & Ciwidey & 808 & $644 \leq \mathrm{TS}<1.008$ & Cukup Layak \\
\hline 2 & & Rancabali & 1.018 & $1.008 \leq \mathrm{TS}<1.680$ & Layak \\
\hline 3 & & Pasirjambu & 894 & $644 \leq \mathrm{TS}<1.008$ & Cukup Layak \\
\hline 4 & & Cimaung & 803 & $644 \leq \mathrm{TS}<1.008$ & Cukup Layak \\
\hline 5 & & Pangalengan & 1.223 & $1.008 \leq \mathrm{TS}<1.680$ & Layak \\
\hline 6 & & Kertasari & 743 & $644 \leq \mathrm{TS}<1.008$ & Cukup Layak \\
\hline 7 & & Pacet & 1.117 & $1.008 \leq \mathrm{TS}<1.680$ & Layak \\
\hline 8 & & Ibun & 969 & $644 \leq \mathrm{TS}<1.008$ & Cukup Layak \\
\hline 9 & & Paseh & 1.005 & $644 \leq \mathrm{TS}<1.008$ & Cukup Layak \\
\hline 10 & & Cikancung & 993 & $644 \leq \mathrm{TS}<1.008$ & Cukup Layak \\
\hline 11 & & Cicalengka & 1.029 & $1.008 \leq \mathrm{TS}<1.680$ & Layak \\
\hline 12 & & Nagreg & 1.029 & $1.008 \leq \mathrm{TS}<1.680$ & Layak \\
\hline 13 & & Rancaekek & 1.180 & $1.008 \leq \mathrm{TS}<1.680$ & Layak \\
\hline 14 & & Majalaya & 1.071 & $1.008 \leq \mathrm{TS}<1.680$ & Layak \\
\hline 15 & & Solokanjeruk & 928 & $644 \leq \mathrm{TS}<1.008$ & Cukup Layak \\
\hline 16 & & Ciparay & 1.146 & $1.008 \leq \mathrm{TS}<1.680$ & Layak \\
\hline 17 & & Baleendah & 1.095 & $1.008 \leq \mathrm{TS}<1.680$ & Layak \\
\hline 18 & & Arjasari & 881 & $644 \leq \mathrm{TS}<1.008$ & Cukup Layak \\
\hline 19 & & Banjaran & 1.000 & $644 \leq \mathrm{TS}<1.008$ & Cukup Layak \\
\hline 20 & & Cangkuang & 819 & $644 \leq \mathrm{TS}<1.008$ & Cukup Layak \\
\hline 21 & & Pamengpeuk & 811 & $644 \leq \mathrm{TS}<1.008$ & Cukup Layak \\
\hline 22 & & Katapang & 950 & $644 \leq \mathrm{TS}<1.008$ & Cukup Layak \\
\hline 23 & & Soreang & 862 & $644 \leq \mathrm{TS}<1.008$ & Cukup Layak \\
\hline 24 & & Kutawaringin & 872 & $644 \leq \mathrm{TS}<1.008$ & Cukup Layak \\
\hline 25 & & Margaasih & 1.018 & $1.008 \leq \mathrm{TS}<1.680$ & Layak \\
\hline 26 & & Margahayu & 1.022 & $1.008 \leq \mathrm{TS}<1.680$ & Layak \\
\hline 27 & & Dayeuhkolot & 1.017 & $1.008 \leq \mathrm{TS}<1.680$ & Layak \\
\hline 28 & & Bojongsoang & 1.044 & $1.008 \leq \mathrm{TS}<1.680$ & Layak \\
\hline 29 & & Cileunyi & 1.054 & $1.008 \leq \mathrm{TS}<1.680$ & Layak \\
\hline 30 & & Cilengkrang & 812 & $644 \leq \mathrm{TS}<1.008$ & Cukup Layak \\
\hline 31 & & Cimenyan & 853 & $644 \leq \mathrm{TS}<1.008$ & Cukup Layak \\
\hline \multicolumn{3}{|c|}{ JUMLAH } & 30.066 & & \\
\hline \multicolumn{3}{|c|}{ RATA - RATA } & 970 & & \\
\hline \multicolumn{3}{|c|}{ TOTAL SKOR MINIMAL } & 743 & & \\
\hline
\end{tabular}




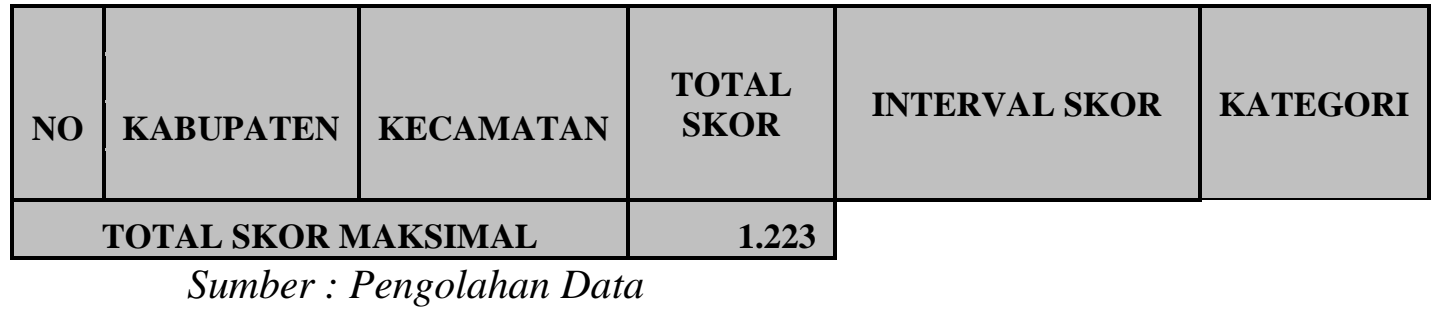

Tabel 4.2

Perbandingan Potensi Wilayah Kecamatan di Kabupaten Bandung

\begin{tabular}{|c|c|c|c|c|c|c|}
\hline NO & KECAMATAN & DESA & $\begin{array}{c}\text { TOTAL } \\
\text { SKOR }\end{array}$ & SELISIH & PERSENTASE & $\begin{array}{c}\text { JUMLAH } \\
\text { NOMINATIF } \\
\text { KECAMATAN }\end{array}$ \\
\hline 1 & Ciwidey & 7 & 808 & 65 & 9 & 1 \\
\hline 2 & Rancabali & 5 & 1018 & 275 & 37 & 2 \\
\hline 3 & Pasirjambu & 10 & 894 & 151 & 20 & 1 \\
\hline 4 & Cimaung & 10 & 803 & 60 & 8 & 1 \\
\hline 5 & Pangalengan & 13 & 1223 & 480 & 65 & 2 \\
\hline 6 & Kertasari & 7 & 743 & 0 & 0 & 1 \\
\hline 7 & Pacet & 13 & 1117 & 374 & 50 & 2 \\
\hline 8 & Ibun & 12 & 969 & 226 & 30 & 1 \\
\hline 9 & Paseh & 12 & 1005 & 262 & 35 & 1 \\
\hline 10 & Cikancung & 9 & 993 & 250 & 34 & 1 \\
\hline 11 & Cicalengka & 12 & 1029 & 286 & 38 & 2 \\
\hline 12 & Nagreg & 6 & 1029 & 286 & 38 & 2 \\
\hline 13 & Rancaekek & 13 & 1180 & 437 & 59 & 2 \\
\hline 14 & Majalaya & 11 & 1071 & 328 & 44 & 2 \\
\hline 15 & Solokanjeruk & 7 & 928 & 185 & 25 & 1 \\
\hline 16 & Ciparay & 14 & 1146 & 403 & 54 & 2 \\
\hline 17 & Baleendah & 8 & 1095 & 352 & 47 & 2 \\
\hline 18 & Arjasari & 11 & 881 & 138 & 19 & 1 \\
\hline 19 & Banjaran & 11 & 1000 & 257 & 35 & 1 \\
\hline 20 & Cangkuang & 7 & 819 & 76 & 10 & 1 \\
\hline 21 & Pamengpeuk & 6 & 811 & 68 & 9 & 1 \\
\hline 22 & Katapang & 7 & 950 & 207 & 28 & 1 \\
\hline 23 & Soreang & 10 & 862 & 119 & 16 & 1 \\
\hline 24 & Kutawaringin & 11 & 872 & 129 & 17 & 1 \\
\hline 25 & Margaasih & 6 & 1018 & 275 & 37 & 2 \\
\hline 26 & Margahayu & 5 & 1022 & 279 & 38 & 2 \\
\hline 27 & Dayeuhkolot & 6 & 1017 & 274 & 37 & 2 \\
\hline 28 & Bojongsoang & 6 & 1044 & 301 & 41 & 2 \\
\hline 29 & Cileunyi & 6 & 1054 & 311 & 42 & 2 \\
\hline 30 & Cilengkrang & 6 & 812 & 69 & 9 & 1 \\
\hline
\end{tabular}




\begin{tabular}{|c|c|c|c|c|c|c|}
\hline NO & KECAMATAN & DESA & $\begin{array}{c}\text { TOTAL } \\
\text { SKOR }\end{array}$ & SELISIH & PERSENTASE & $\begin{array}{c}\text { JUMLAH } \\
\text { NOMINATIF } \\
\text { KECAMATAN }\end{array}$ \\
\hline 31 & Cimenyan & 9 & 853 & 110 & 15 & 1 \\
\hline \multicolumn{7}{|c|}{ Jumlah Pemekaran } \\
\hline
\end{tabular}

Sumber : Pengolahan Data

Kecamatan yang memiliki potensi sama dengan atau lebih besar dari potensi wilayah kecamatan terkecil sebesar 30\%, maka dapat dikatakan kecamatan itu memiliki potensi yang besar untuk dimekarkan. Berdasarkan tabel 4.65 diperoleh hasil dari jumlah kecamatan yang ada sebanyak 31 (tiga puluh satu) kecamatan menjadi 45 (empat puluh lima) kecamatan nominatif apabila dimekarkan. Kecamatan yang layak dan berpotensi lebih baik untuk dimekarkan adalah Kecamatan Rancabali, Pangalengan, Pacet,
Cicalengka, Nagreg, Rancaekek, Majalaya, Ciparay, Baleendah, Margaasih, Margahayu, Dayeuhkolot, Bojongsoang, dan Cileunyi. Dari 14 (empat belas) kecamatan yang layak dimekarkan dibentuk masing-masing kecamatan induk dan kecamatan hasil pemekaran, sehingga jumlah kecamatan yang layak dimekarkan dari 31 menjadi 45 kecamatan.

\subsection{Pemetaan Kecamatan di Kabupaten Bandung.}

Berdasarkan hasil analisa di atas, diperoleh pemetaan kecamatan di Kabupaten Bandung sebagai berikut:

Tabel 4.3

Pemetaan Wilayah Kecamatan di Kabupaten Bandung

\begin{tabular}{|c|c|c|}
\hline NO & $\begin{array}{c}\text { KECAMATAN } \\
\text { NOMINATIF } \\
\text { CUKUP LAYAK DIMEKARKAN }\end{array}$ & $\begin{array}{c}\text { KECAMATAN } \\
\text { NOMINATIF } \\
\text { LAYAK DIMEKARKAN }\end{array}$ \\
\hline 1 & Ciwidey & Rancabali \\
\hline 2 & Pasirjambu & Pangalengan \\
\hline 3 & Cimaung & Pacet \\
\hline 4 & Kertasari & Cicalengka \\
\hline 5 & Ibun & Nagreg \\
\hline 6 & Paseh & Rancaekek \\
\hline 7 & Cikancung & Majalaya \\
\hline 8 & Solokanjeruk & Ciparay \\
\hline 9 & Arjasari & Baleendah \\
\hline
\end{tabular}




\begin{tabular}{|c|c|c|}
\hline 10 & Banjaran & Margaasih \\
\hline 11 & Cangkuang & Margahayu \\
\hline 12 & Pamengpeuk & Dayeuhkolot \\
\hline 13 & Katapang & Bojongsoang \\
\hline 14 & Soreang & Cileunyi \\
\hline 15 & Kutawaringin & \\
\hline 16 & Cilengkrang & \\
\hline 17 & Cimenyan & \\
\hline
\end{tabular}

Berdasarkan tabel 4.3 potensi yang besar untuk terdapat 14 kecamatan dalam dimekarkan. Berdasarkan tabel 4.65 kategori layak dimekarkan yaitu diperoleh hasil dari jumlah kecamatan Rancabali, Pangalengan, kecamatan yang ada sebanyak 31 Pacet, Cicalengka, Nagreg, (tiga puluh satu) kecamatan menjadi Rancaekek, Majalaya, Ciparay, 45 (empat puluh lima) kecamatan Baleendah, Margaasih, Margahayu, nominatif apabila dimekarkan. Dayeuhkolot, Bojongsoang, dan Kecamatan yang layak dan Cileunyi. Sedangkan potensi wilayah berpotensi lebih baik untuk kecamatan dalam kategori cukup dimekarkan adalah Kecamatan layak dimekarkan ada 17 kecamatan yaitu: Ciwidey, Pasirjambu, Cimaung, Kertasari, Ibun, Paseh, Cikancung, Solokanjeruk, Arjasari, Banjaran, Cangkuang, Pamengpeuk, Katapang, Soreang, Kutawaringin, Cilengkrang, Cimenyan.

Kecamatan yang memiliki nilai skor minimal adalah Kecamatan Kertasari sebesar 743. Kecamatan yang memiliki nilai maksimal adalah Kecamatan Pangalengan sebesar 1.223. Perbedaan potensi wilayah kecamatan antara yang terbesar dan terkecil sebesar 480 atau $65 \%$ dari potensi wilayah kecamatan yang terkecil.

Kecamatan yang memiliki potensi sama dengan atau lebih besar dari potensi wilayah kecamatan terkecil sebesar 30\%, maka dapat dikatakan kecamatan itu memiliki

Rancabali, Pangalengan, Pacet, Cicalengka, Nagreg, Rancaekek, Majalaya, Ciparay, Baleendah, Margaasih, Margahayu, Dayeuhkolot, Bojongsoang, dan Cileunyi. Dari 14 (empat belas) kecamatan yang layak dimekarkan dibentuk masing-masing kecamatan induk dan kecamatan hasil pemekaran, sehingga jumlah kecamatan yang layak dimekarkan dari 31 menjadi 45 kecamatan.

\section{KESIMPULAN}

Berdasarkan uraian pada penjelasan di atas, dapat ditarik kesimpulan sebagai berikut:

1. Pemekaran Kecamatan di Kabupaten Bandung didasarkan pada tingkat kemampuan atau potensi masing-masing kecamatan melalui pengukuran 
dan penilaian variabel utama dan variabel pendukung. Adapun 19 (sembilan belas) variabel penelitian yaitu demografi, orbitasi, pendidikan, kesehatan, prasarana ibadah, sarana olah raga, transportasi, komunikasi, penerangan umum, kesadaran politik, keamanan dan ketertiban masyarakat, pertanian, perikanan, peternakan, ketenagakerjaan, sosial budaya, ekonomi masyarakat, sosial masyarakat, dan aspek pemerintahan.

Suatu kecamatan dapat dimekarkan jika kecamatan memiliki potensi dalam interval tinggi $(1.008 \leq \mathrm{TS}<1.680)$. Dapat dimekarkan dengan syarat jika potensinya dalam interval $(644 \leq \mathrm{TS}<1.008)$, dan dinyatakan tidak lulus atau ditolak untuk dimekarkan jika masing-masing kecamatan hanya mencapai total skor kurang dari 644.

2. Hasil penilaian dan pengukuran terhadap potensi kecamatan di Kabupaten Bandung dapat dijelaskan sebagai berikut :

Skoring data sekunder monografi desa terhadap 31 kecamatan yang akan dimekarkan diperoleh hasil bahwa terdapat 14 (empat belas) kecamatan dalam kategori layak dimekarkan yaitu kecamatan Rancabali, Pangalengan, Pacet, Cicalengka, Nagreg, Rancaekek, Majalaya, Ciparay, Baleendah, Margaasih, Margahayu,
Dayeuhkolot, Bojongsoang, dan

Cileunyi.

\section{SARAN}

Untuk menjamin keberhasilan implementasi penataan dan pengembangan kewilayahan dapat dilihat dari kemampuan pemerintah dari tingkat yang terendah hingga yang tertinggi dalam menyelenggarakan pelayanan, pemerintahan dan pembangunan secara efektif dan efisien dapat disusun rekomendasi sebagai berikut

1. Mengingat ada tiga alternatif yang disodorkan, diharapkan adanya pola pengembangan yang berkelanjutan. Kecamatan merupakan perangkat daerah kabupaten/kota, perlu kiranya dibentuk pola pelimpahan sebagian kewenangan dari Bupati di Kabupaten Bandung dikarenakan medan yang sangat berat.

2. Menyusun desain organisasi kecamatan menurut potensi dan karakteristik kecamatan (tipologi kecamatan) serta pola dan sifat kewenangan camat yang dilimpahkan dari Bupati;

\section{DAFTAR PUSTAKA}

Anthony, Robert N ; John Dearden ; Northon M. Bedford ; 1985, Sistem Pengendalian Manajemen ; terjemahan ; edisi ke-5 Penerbit Erlangga, Jakarta. 
Anthony, Robert N and Regma E. Herzlinger;1980,

Management Control in Nonprofit Organizations ; Revised Edition; Richard D. Irwin, Inc. Homewood, Illinois.

Argyris, Chris, 1960, Understanding Organizational Behaviour, The Dorsey Press, Inc. Homewood Illinois.

Herbert, Theodore .T, 1976, Organizational Behaviour Readings and Cases, Macmillan Publishing Co. Inc, Newyork.

Koontz, Harold, Cyril O'Donnell and Heinz Weihrich, 1980. Management. Seventh Edition. McGraw-Hill International Book Company, Japan.

Luthans, Fred; Organizational Behaviour, 1981, Third Edition, McGraw Hill International Book Company, Tokyo.
Terry, George R, 1960. Principles of Management. Thrid Edition. Richard D. Irwin Inc. Homewood Illinois. Sadu Wasistiono, dkk, penyunting, 2002.

Wasistiono, Sadu. 2001. Menata Ulang Kelembagaan Kecamatan. Pusat Kajian Pemerintahan STPDN. Penerbit PT Citra Pindo, Bandung.,

Selekta Penyelenggaraan Pemerintahan Daerah. Edisi Ketiga. Penerbit Fokusmedia, Bandung.

Selekta Manajemen Pemerintahan Daerah. Edisi Revisi. Penerbit Fokusmedia, Bandung. 